\title{
ANALISIS PENGARUH FAKTOR-FAKTOR PSIKOLOGIS MAHASISWA TERHADAP KEBERHASILAN MENDAPAT GELAR SARJANA DI BIDANG AKUNTANSI
}

\author{
Luh Kade Datrinia, ${ }^{*}$, Komang Adi Kurniawan Saputrab, I Made Andika \\ Pradnyana Wistawanc \\ a,b,cUniversitas Warmadewa, Л. Terompong No.24, Sumerta Kelod, \\ Denpasar Tim., Kota Denpasar, Bali, Indonesia \\ *(datriniluhkade@yahoo.co.id)
}

\begin{abstract}
ABSTRAK
Penelitian ini bertujuan untuk menguji pengaruh perilaku belajar, motivasi belajar, kecerdasan emosional, kecerdasan intelektual dan kecerdasan spiritual terhadap keberhasilan mahasiswa akuntansi meraih gelar sarjana. Penelitian ini dilakukan menggunakan metode kuantitatif melalui survey menggunakan kuesioner. Untuk menguji antar variabel dilakukan uji regresi linear berganda, tetapi sebelumnya dilakukan uji validitas dan reliabilitas terhadap instrument penelitian serta uji asumsi klasik yang meliputi uji normalitas, heterokedastisitas dan multikolinearitas. Populasi penelitian ini adalah mahasiswa akuntansi pada perguruan tinggi negeri dan swasta di provinsi Bali berjumlah 8.652 orang pada tahun 2018. Teknik sampling dibantu dengan rumus slovin sehingga didapatkan sampel sejumlah 100 orang mahasiswa yang tersebar diseluruh Kabupaten di Provinsi Bali. Hasil penelitian ini adalah perilaku belajar, motivasi belajar, kecerdasan emosional, kecerdasan intelektual dan kecerdasan spiritual berpengaruh positif signifikan terhadap keberhasilan mahasiswa akuntansi meraih gelar sarjana.
\end{abstract}

Kata kunci: kecerdasan emosional, kecerdasan intelektual, kecerdasan spiritual, sarjana akuntansi

\begin{abstract}
This study aims to examine the effect of learning behavior, learning motivation, emotional intelligence, intellectual intelligence and spiritual intelligence on the success of accounting students achieving a bachelor's degree. This research was conducted using quantitative methods through surveys using questionnaires. To refer between variables, multiple linear regression tests were carried out, but the validity and reliability of the research instruments and the classical assumption tests were carried out which included tests of normality, heteroscedasticity and multicollinearity. The population of this study is accounting students in state and private universities in the province of Bali, amounting to 8,652 people in 2018. The sampling technique is assisted by the Slovin formula so that a sample of 100 students is spread throughout the regencies of Bali Province. The results of this study are learning behavior, learning motivation, emotional intelligence, intellectual intelligence and spiritual intelligence have a significant effect on the success of accounting students achieving a bachelor's degree.
\end{abstract}

Keywords: emotional intelligence, intellectual intelligence, spiritual intelligence, bachelor of accounting 


\section{PENDAHULUAN}

Pendidikan di Perguruan Tinggi merupakan pembentukan karakter individu yang mendidik mahasiswa untuk siap bekerja. Perguruan Tinggi pastinya akan mengharapkan lulusan yang berkualitas dengan melakukan usaha meningkatkan kualitas pada sistem pembelajarannya. Belajar yang dipahami oleh seoarang mahasiswa berhubungan dengan pembelajaran yang diberikan oleh seorang dosen. Kecerdasan yang dimiliki mahasiswa sangat berpengaruh terhadap kesuksesan dalam memahami pembelajaran. Mahasiswa terkadang merasakan bosan dan jenuh terhadap proses pembelajaran. Hal ini dikarenakan kurangnya memahami mengenai makna belajar diperguruan tinggi. Mahasiswa terbiasa dengan pola belajar menghafal tetapi tidak memahami pelajaran tersebut, sehingga mahasiswa akan cenderung mudah lupa dengan apa yang pernal dipelajari atau kesulitan untuk memahami apa yang diajarkan selanjutnya. Bire (2014) menyatakan bahwa belajar di perguruan tinggi merupakan suatu pilihan strategik dalam mencapai tujuan individual seseorang. Semangat, cara belajar, dan sikap mahasiswa terhadap belajar sangat dipengaruhi oleh kesadaran (motivasi) akan adanya tujuan individual dan tujuan lembaga pendidikan yang jelas. Semua aspek ini, pengukuran prestasi akademik merupakan hal-hal yang sangat penting untuk mengetahui tingkat keberhasilan yang dicapai mahasiswa dalam belajar. Proses belajar diperlukan perilaku belajar yang sesuai dengan tujuan pendidikan, dimana dengan perilaku belajar tersebut tujuan pendidikan dapat dicapai secara efektif dan efisien, sehingga prestasi akademik dapat ditingkatkan.

Sikap psikologis seperti diatas memiliki peran tersendiri dalam meraih sukses seorang mahasiswa. Sikap psikologis yang dimaksud dalam hal ini adalah perilaku belajar, motivasi belajar, kecerdasan emosional, kecerdasan spiritual dan kecerdasan intelektual. Kecerdasan emosional mahasiswa memiliki pengaruh positif terhadap prestasi belajar mahasiswa. Kecerdasan emosional ini mampu melatih kemampuan untuk mengelola perasaannya, kemampuan untuk memotivasi dirinya, kesanggupan untuk tegar dalam menghadapi frustasi, kesanggupan mengendalikan dorongan dan menunda kepuasan sesaat, mengatur suasana hati yang aktif, serta mau berempati dan bekerja sama dengan orang lain. Perlu dipertimbangkan adanya kecerdasan spiritual atau yang 
dikenal Spiritual Quotient yaitu kecerdasan yang digunakan untuk menyelesaikan permasalahan hidup yang dihadapi, manusia dituntut untuk kreatif mengubah penderitaan menjadi semangat (motivasi) hidup yang tinggi sehingga penderitaan berubah menjadi kebahagian hidup dan manusia harus mampu menemukan makna kehidupannya Onah (2015).

Penelitian Rokhana (2016) menyatakan bahwa kecerdasan emosional berpengaruh positif signifikan terhadap tingkat pemahaman akuntansi. Perilaku belajar berpengaruh positif signifikan terhadap tingkat pemahaman akuntansi Trisnawati, dkk., (2017) menyebutkan bahwa ada pengaruh antara perilaku belajar terhadap prestasi belajar mahasiswa.

Berdasarkan latar belakang yang telah diuraikan, maka perlu dilakukan penelitia dengan judul "Analisis Pengaruh Faktor-Faktor Psikologis Mahasiswa Terhadap Keberhasilan Mendapat Gelar Sarjana di Bidang Akuntansi”.

Berdasarkan uraian latar belakang, maka rumusan masalah dalam penelitian ini adalah:

1) Apakah perilaku belajar berpengaruh terhadap tingkat keberhasilan mahasiswa mendapatkan gelar sarjana (S1)?
2) Apakah motivasi belajar berpengaruh terhadap tingkat keberhasilan mahasiswa mendapatkan gelar sarjana (S1)?

3) Apakah kecerdasan emosional berpengaruh terhadap tingkat keberhasilan mahasiswa mendapatkan gelar sarjana (S1)?

4) Apakah kecerdasan intelektual berpengaruh terhadap tingkat keberhasilan mahasiswa mendapatkan gelar sarjana (S1)?

5) Apakah kecerdasan spiritual berpengaruh terhadap tingkat keberhasilan mahasiswa mendapatkan gelar sarjana (S1)?

\section{TELAAH LITERATUR DAN PERUMUSAN HIPOTESIS \\ Teori Psikologi Humanistik}

Penelitian ini menggunakan Teori Psikologi Humanistik karena tingkat keberhasilan mahasiswa tidak terlepas dari pengalaman dan tingkah laku individu. Psikologi humanistik juga memberikan sumbangannya bagi pendidikan alternatif yang dikenal dengan sebutan pendidikan humanistik (humanistic). Teori Psikologi humanistik atau disebut juga dengan nama psokologi kemanusiaan adalah suatu pendekatan yang multifaset terhadap pengalaman dan tingkah laku manusia yang memusatkan perhatian pada keunikan dan aktualisasi diri 
manusia. Psikologi humanistik dapat dimengerti dari tiga ciri utama, yaitu (Wahyudi, 2009):

\section{1) Psikologi}

humanistik menawarkan satu nilai yang baru sebagai pendekatan untuk memahami sifat dan keadaan manusia

2) Psikologi humanistik menawarkan pengetahuan yang luas akan kaedah penyelidikan dalam bidang tingkah laku manusia

3) Psikologi humanistik menawarkan metode yang lebih luas akan kaedah- kaedah yang lebih efektif dalam dalam pelaksanaan psikoterapi.

Menurut Wahyudi (2009), Aliran humanistik memandang bahwa belajar bukan sekedar pengembangan kualitas kognitif saja, melainkan juga sebuah proses yang terjadi dalam diri individu yang melibatkan seluruh domain yang ada. Dengan kata lain, pendekatan humanistik dalam pembelajaran menekankan pentingnya emosi atau perasaan (emotional approach), komunikasi yang terbuka dan nilai-nilai yang dimiliki oleh setiap siswa. Teori psikologi humanistik dapat kita ketahui bahwa teori ini berorientasi mengenai potensi yang rasional dan mengoptimalakan kempuan individu secara keseluruhan dengan pembelajaran yang nyata. Sedangkan tingkat keberhasilan yaitu bagaimana mahasiswa dapat mengerti terhadap apa yang sudah dipelajari. Dari dua aspek tersebut dapat diketahui tingkah laku mahasiswa dalam proses pembelajaran individu tersebut berpengaruh terhadap tingkat keberhasilan.

\section{Perilaku Belajar}

Menurut Hanifah (2001) perilaku belajar adalah kebiasaan belajar yang dilakukan oleh individu secara berulang-ulang sehingga menjadi otomatis atau langsung secara sepontan. Perilaku belajar tidak dirasakan sebagai beban, tetapi sebagai kebutuhan. Hal ini tercipta karena terus menerus dilakukan dengan bimbingan dan pengawasan serta keteladanan dalam semua aspek dan kreatifitas pendidikan.

\section{Motivasi Belajar}

Motivasi belajar adalah keseluruhan daya penggerak dalam diri mahasiswa itu sendiri yang menimbulkan kegiatan belajar dan memberikan arah pada kegiatan belajar, sehingga tujuan yang dikehendaki oleh subjek belajar itu dapat tercapai. Motivasi belajar mahasiswa dapat didefinisikan sebagai suatu keadaan dalam diri mahasiswa yang mendorong dan mengarahkan perilakunya kepada 
tujuan yang ingin dicapainya dalam mengikuti pendidikan tinggi. Motivasi penting karena dengan motivasi ini diharapkan setiap individu mau bekerja keras dan antusias untuk mencapai produktivitas kerja yang tinggi.

\section{Kecerdasan Emosional}

Kecerdasan emosional yang ditandai oleh kemampuan pengenalan diri, pengendalian diri, motivasi diri, empati dan kemampuan sosial akan mempengaruhi perilaku belajar mahasiswa yang nantinya juga mempengaruhi seberapa besar mahasiswa yang mendapatkan gelar sarjana (Khaerani \& Wibowo, 2014). Kecerdasan emosional sebagai kemampuan lebih memiliki seseorang dalam memotivasi diri, ketahanan dalam menghadapi kegagalan, mengendalikan emosi, dan menunda kepuasan serta mengatur keadaan jiwa. Kecerdasan emosional tersebut seseorang dapat menempatkan emosinya pada porsi yang tepat, memilih kepuasan, dan mengatur suasana hati. Menerapkan energi emosi yang efektif dalam kehidupan dan pekerjaan sehari-hari.

\section{Kecerdasan Intelektual}

Kecerdasan intelektual sering juga disebut inteligensi, yang berarti kemampuan kognitif yang dimiliki suatu organisme untuk menyesuaikan diri secara efektif pada lingkungan yang komplek dan selalu berubah serta dipengaruhi oleh faktor genentik menurut Onah (2015). Berdasarkan pengertian yang dikemukakan diatas maka dapat disimpulkan bahwa kecerdasan intelektual adalah istilah umum yang digunakan untuk menggambarkan sifat pikiran yang mencakup sejumlah kemampuan, seperti kemampuan untuk berpikir, merencanakan, memecahkan masalah, berpikir abstrak, memahami ide-ide, penggunaan bahasa, dan pembelajaran.

\section{Kecerdasan Spiritual}

Spiritual Intelligence adalah istilah yang digunakan untuk menunjukkan kerohanian yang berkorelasi dengan IQ (Intelligence Quotient) dan EQ (Emotional Quotient). Seperti EQ, Spiritual Intelligence menjadi lebih utama dalam penyelidikan ilmiah dan diskusi filosofis/psikologis. Ini merujuk kepada sekelompok atau serangkaian kecenderungan yang terdiri dari persepsi, intuisi, kognisi, yang berkaitan dengan spiritualitas dan/atau religiusitas, khususnya modal spiritual (Atmadja dan Saputra, 2014). 
Datrini, Saputra, Wistawan - Analisis Pengaruh Faktor-faktor Psikologis ...

Perilaku Belajar pada Tingkat

Keberhasilan

Mahasiswa

Mendapatkan Gelar Sarjana (S1)

Menurut Rachmi (2010) perilaku belajar adalah kebiasaan belajar yang dilakukan oleh individu secara berulang-ulang sehingga menjadi otomatis atau langsung secara sepontan. Penelitian Rokhana (2016) menyimpulkan bahwa perilaku belajar berpengaruh positif signifikan terhadap tingkat pemahaman akuntansi, Trisnawati, dkk (2017) menyatakan bahwa ada pengaruh antara perilaku belajar terhadap prestasi belajar mahasiswa. Uraian tersebut dapat dirumuskan hipotesis sebagai berikut:

$\mathrm{H}_{1}$ : Perilaku belajar mahasiswa berpengaruh positif terhadap tingkat keberhasilan mahasiswa mendapatkan gelar sarnaja (S1).

\section{Motivsasi Belajar pada Tingkat} Keberhasilan Mahasiswa

Mendapatkan Gelar Sarjana (S1)

Motivasi merupakan keadaan didalam diri individu yang menyebabkan seseorang melakukan suatu kegiatan untuk mencapai tujuan tertentu. Motivasi yang kuat seseorang akan berusaha dengan sungguh-sungguh untuk mencapai tujuan tersebut. Jika siswa mempunyai motivasi yang kuat untuk belajar maka ia akan berusaha untuk belajar dengan sebaik-baiknya. Jadi, jelas bila seorang siswa ingin mencapai tujuan yaitu hasil belajar yang maksimal selain mempunyai pengetahuan juga harus mempunyai motivasi belajar. Menurut Sudrajat motivasi dapat diartikan sebagai kekuatan (energi) seseorang yang dapat menimbulkan tingkat persistensi dan antusiasmenya dalam melaksanakan suatu kegiatan, baik yang bersumber dari dalam diri individu itu sendiri (motivasi intrinsik) maupun dari luar individu (motivasi ekstrinsik). Penelitian Syamsuddin (2014) menyimpulkan bahwa motivasi belajar berpengaruh positif terhadap prestasi belajar mahasiswa akuntansi. Uraian tersebut dapat dirumuskan hipotesis sebagai berikut:

$\mathrm{H}_{2}$ : Motivasi belajar mahasiswa berpengaruh positif terhadap tingkat keberhasilan mahasiswa mendapatkan gelar sarnaja (S1).

\section{Kecerdasan Emosional pada}

Tingkat Keberhasilan Mahasiswa Mendapatkan Gelar Sarjana (S1)

Kecerdasan emosional sebagai kemampuan lebih memiliki seseorang dalam memotivasi diri, ketahanan dalam menghadapi kegagalan, mengendalikan emosi, dan menunda kepuasan serta mengatur keadaan jiwa. Komponen kecerdasan emosional berupa pengenalan diri, pengendalian diri, dsn motivasi. 
Kecerdasan emosional tersebut seseorang dapat menempatkan emosinya pada porsi yang tepat, memilih kepuasan, dan mengatur suasana hati. Menurut Rokhana (2016) dan Hatima, dkk (2017) menyatakan bahwa kecerdasan emosional berpengaruh terhadap prestasi mahasiswa. Uraian tersebut dapat dirumuskan hipotesis sebagai berikut:

$\mathrm{H}_{3}$ : Kecerdasan emosional berpengaruh positif terhadap tingkat keberhasilan mahasiswa mendapatkan gelar sarjana (S1).

\section{Kecerdasan Intelektual pada}

Tingkat Keberhasilan Mahasiswa Mendapatkan Gelar Sarjana (S1)

Salah satu ukuran kecerdasan yang sudah sangat akrab ditelingan manusia adalah kecerdasan intelektual. Kecerdasan intelektual sering juga disebut inteligensi, yang berarti kemampuan kognitif yang dimiliki suatu organisme untuk menyesuaikan diri secara efektif pada lingkungan yang komplek dan selalu berubah serta dipengaruhi oleh faktor genentik, menurut Onah (2015). Halhal yang berhubungan dengan kecerdasan intelektual yaitu, kemampuan memecahkan masalah, intelegensi verbal dan intelegensi praktis. Mahasiswa yang mempunyai kecerdasan intelektual yang baik menimbulkan rasa keingintahuan.
Penelitian khusnul Hatima, dkk., (2017) menyatkan bahwa kecerdasan itelektual berpengaruh pada prestasi akademik mahasiswa. Uraian tersebut dapat dirumuskan hipotesis sebagai berikut:

$\mathrm{H}_{4}$ : Kecerdasan intelektual berpengaruh positif terhadap tingkat keberhasilan mahasiswa mendapatkan gelar sarjana (S1).

\section{Kecerdasan Spiritual pada Tingkat}

\section{Keberhasilan \\ Mahasiswa}

Mendapatkan Gelar Sarjana (S1).

Istilah Spiritual berasal dari bahasa latin spiritus yang berarti prinsip yang memvasilitasi suatu organisme, atau bisa juga berasal dari bahasa Latin sapientia sophia dalam bahasaYunani yang berarti "kearifan". Kecerdasan Spriritual adalah kecerdasan jiwa, keceerdasan yang berada didalam di diri yang dalam, diluar ego atau pikiran sadar. Kita dapat menggunakan kecerdasan spiritual untuk menjadi lebih cerdas secara spiritual dan beragama Onah (2015). Kecerdasan spiritual yang baik dapat dilihat dari kemampuan bersikap fleksibel, kesadaran diri yang tinggi, kemampuan untuk menghadapi dan melampaui rasa sakit. Spiritualis mahasiswa yang cerdas akan mampu membantu dalam memecahkan permasalahan sehingga mahasiswa dapat bersikap tenang dalam menghadapi masalah- 
Datrini, Saputra, Wistawan - Analisis Pengaruh Faktor-faktor Psikologis ...

masalah kendala- kendala dalam proses mendapatkan gelar sarjana (S1). Uraian tersebut dapat dirumuskan hipotesis sebagai berikut:

$\mathrm{H}_{5}$ : Kecerdasan spiritual berpengaruh positif terhadap tingkat keberhasilan mahasiswa mendapatkan gelar sarjaan (S1).

\section{METODE}

\section{Populasi dan Metode Penentuan \\ Sampel}

Penelitian ini dilaksanakan pada seluruh mahasiswa akuntansi di 5 (lima) Universitas di Bali yang memiliki Prodi Akuntansi Strata 1 (satu) dengan jumlah populasinya sebanyak 8.652 mahasiswa akuntansi. Apabila jumlah populasi besar maka perlu melakukan penarikan sampel. Penggunaan sampel ini bertujuan untuk memperoleh keterangan-keterangan mengenai populasi dari mana sampel tersebut dipilih karena jumlah populasi yang besar. Untuk menentukan jumlah minimal sampel yang dibutuhkan untuk ukuran populasi, dapat diketahui dengan menggunakan rumus Slovin.

Tabel 1. Lima Besar Kampus di Bali Berdasarkan Jumlah Mahasiswa

\begin{tabular}{clc}
\hline No & \multicolumn{1}{c}{ Nama Kampus } & Jumlah \\
\hline 1 & Universitas Udayana & 16.659 \\
2 & Universitas Pendidikan Ganesha & 11.954 \\
3 & Universitas Warmadewa & 10.784 \\
4 & Universitas Mahasaraswati & 10.403 \\
5 & Universitas Hindu Indonesia & 3.972 \\
\hline
\end{tabular}
Sumber: Pangkalan Data Perguruan Tinggi, 2017 (data diolah)

Berdasarkan data diatas, maka dapat diidentifikasi bahwa penelitian ini dapat dilakukan dengan memilih lima besar perguruan tinggi dengan jumlah mahasiswa terbanyak. Itu artinya bahwa, dengan banyaknya jumlah mahasiswa maka universitas tersebut banyak diminati. Namun, untuk lebih spesifik maka berikut disajikan data jumlah mahasiswa akuntansi di lima kampus yang memiliki jumlah mahasiswa terbanyak di Bali, yaitu: 
Tabel 2. Jumlah Mahasiswa Akuntansi di Lima Besar Kampus di Bali

\begin{tabular}{clc}
\hline No & \multicolumn{1}{c}{ Nama Kampus } & $\begin{array}{c}\text { Jml. Mahasiswa } \\
\text { Akuntansi }\end{array}$ \\
\hline 1 & Universitas Udayana & 1.065 \\
2 & Universitas Pendidikan Ganesha & 1.303 \\
3 & Universitas Warmadewa & 2.298 \\
4 & Universitas Mahasaraswati & 2.846 \\
5 & Universitas Hindu Indonesia & 1.140 \\
& $\quad$ Jumlah & 8.652
\end{tabular}

Sumber: Pangkalan Data Perguruan Tinggi, 2017 (data diolah)

Sesuai dengan data dari pangkalan data perguruan tinggi yang dirilis secara nasional setiap tahunnya, maka total jumlah mahasiswa akuntansi yang kuliah di lima universitas besar di Bali yaitu sejumlah 8.652 orang. Sehingga populasi penelitian ini berjumlah 8.652 orang mahasiswa akuntansi. Berikut perhitungan sampel menggunakan rumus slovin:

$$
\mathrm{n}=\frac{\mathrm{N}}{1+\mathrm{N}(\mathrm{d})^{2}}
$$

Keterangan:

$\mathrm{n}$ : Besar sampel

$\mathrm{N}$ : Besar populasi

d: Tingkat ketepatan yang diinginkan $(0,1)$

Sehingga dapat diperoleh jumlah sampel dalam penelitian ini adalah :

$$
\mathrm{n}=\frac{8.652}{1+8.652(0,1)^{2}}
$$

$\mathrm{n}=98,86$ sampel, dibulatkan menjadi 100 sampel keseluruhan. Dengan klasifikasi 20 sampel mahasiswa setiap Perguruan Tinggi.

\section{Definisi Operasional Variabel}

Perilaku Belajar

Perilaku belajar adalah kebiasaan belajar yang dilakukan oleh individu secara berulang-ulang sehingga menjadi otomatis atau langsung secara sepontan. Maka alat ukur yang digunakan untuk mengukur variabel perilaku belajar yaitu dengan menggunakan kuisioner menggunakan empat skala likert dari sangat tidak setuju (point 1) sampai dengan sanga setuju (point 4), yaitu: kebiasaan mengikuti pelajaran, kebiasaan membaca buku, kunjungan ke perpustakaan, kebiasaan menghadapi ujian. Kuesioner penelitian dikembangkan dengan mengacu pada penelitian terdahulu dari Rachmi (2010). 
Motivasi Belajar

Motivasi belajar memiliki peranan penting terhadap pencapaian prestasi belajar mahasiswa. Dalam kenyataannya, motivasi ini dapat menimbulkan kegigihan/semangat kepada mahasiswa untuk mencapai prestasi yang tinggi. Instrumen ini menggunakan empat skala likert dari sangat tidak setuju (point 1) sampai dengan sangat setuju (point 4). Maka alat ukur yang digunakan untuk mengukur variabel motivasi belajar yaitu dengan menggunakan kuisioner yaitu: adanya hasrat dan keinginan untuk berhasil, adanya penghargaan dalam belajar, adanya lingkungan belajar yang kondusif, sehingga memungkinkan seorang mahasiswa belajar dengan baik.

\section{Kecerdasan Emosional}

Kecerdasan emosional sebagai kemampuan lebih memiliki seseorang dalam memotivasi diri, ketahanan dalam menghadapi kegagalan, mengendalikan emosi, dan menunda kepuasan serta mengatur keadaan jiwa. Menurut Rachmi (2010). Instrumen ini menggunakan empat skala likert dari sangat tidak setuju (point 1) sampai dengan sangat setuju (point 4). Maka alat ukur yang digunakan untuk mengukur variabel kecerdasan emosional yaitu dengan menggunakan kuisioner yaitu: pengenalan diri, pengendalian diri, motivasi, empati, keterampilan sosial

\section{Kecerdasan Intelektual}

Kecerdasan intelektual sering juga disebut inteligensi, yang berarti kemampuan kognitif yang dimiliki suatu organisme untuk menyesuaikan diri secara efektif pada lingkungan yang komplek dan selalu berubah serta dipengaruhi oleh faktor genentik, menurut Onah (2015). Instrumen ini menggunakan empat skala likert dari sangat tidak setuju (point 1) sampai dengan sangat setuju (point 4). Maka alat ukur yang digunakan untuk mengukur variabel kecerdasan intelektual yaitu dengan menggunakan kuisioner yaitu: kemampuan memecahkan masalah, intelegensi verbal, intelegensi praktis.

\section{Kecerdasan Spiritual}

Kecerdasan Spriritual adalah kecerdasan jiwa, keceerdasan yang berada didalam di diri yang dalam, diluar ego atau pikiran sadar. Kita dapat menggunakan kecerdasan spiritual untuk menjadi lebih cerdas secara spiritual dan beragama Onah (2015). Kecerdasan spiritual yang baik dapat dilihat dari kemampuan bersikap fleksibel, kesadaran diri yang tinggi, dan kemampuan untuk menghadapi dan melampaui rasa sakit. Instrumen ini menggunkan empat skala likert dari sngat tidak 
setuju (point 1) sampai dengan sangat setuju (point 4). Maka alat ukur yang digunakan untuk mengukur variabel kecerdasan spiritual yaitu dengan menggunakan kuisioner yaitu: bersikap fleksibel, kesadaran diri, menghadapi dan memanfaatkan penderitaan

Kesuksesan dalam Meraih Gelar Sarjana (S1)

Sarjana adalah gelar akademik yang diberikan kepada lulusan program pendidikan Sarjana (S-1). Gelar sarjana pada saat ini memang menjadi tolak ukur, seberapa berkualitas seseorang, seberapa berpendidikan dan biasanya para sarjana mayoritas lebih memiliki keungulan dibandingkan mereka yang tidak mengenyam bangku sekolah atau kuliah. Instrumen ini menggunakan skala likert dari sangat tidak setuju (point 1) sampai dengan sangat setuju (point 4). Untuk mengukur variabel kesusksesan meraih gelar sarjana (S1) yaitu dengan menggunakan kuisioner yaitu: biaya pendidikan, kondisi lingkungan, dorongan dari keluarga.

\section{Metode Pengumpulan Data}

Metode pengumpulan data pada penelitian ini dengan survey. Kuesioner yang disebarkan berupa daftar pertanyaan atau pernyataan tertulis kepada responden mengenai pengaruh perilaku belajar, kecerdasan emosional, kecerdasan intelektual, dan kecerdasan spiritual terhadap tingkat keberhasilan mahasiswa mendapatkan gelar S1 pada mahasiswa universitas warmadewa

\section{Teknik Analisis Data}

Uji Validitas

Pengujian validitas dilakukan dengan cara menghitung korelasi antara skor masing-masing butiran pertanyaan dengan skor total sehingga diperoleh nilai pearson correlation. Apabila korelasi antara skor masing-masing butir pertanyaan dengan skor total menunjukkan nilai koefisien korelasinya $\geq 0,3$ maka masing-masing butir pertanyaan dapat dikatakan valid. Uji validitas dilakukan dengan bantuan fasilitas program SPSS (Statistic Package for Sosial Science).

Uji Reliabilitas

Suatu kuesioner dikatakan reliable atau handal jika jawaban seseorang terhadap pertanyaan adalah konsisten atau stabil dari waktu ke waktu (Ghozali, 2016:47. Untuk mengukur reliabilitas digunakan program SPSS (Statistic Package for Sosial Science) dengan uji statistik cronbach alpha (a). Suatu variabel dikatakan reliabel jika 
memberikan nilai Cronbach Alpha> 0,70 .

\section{Uji Normalitas}

Model regresi yang baik adalah data yang terdistribusi normal. Caranya adalah dengan membandingkan hasil dari Kolmogorov-Smirnov (K-S) hitung dengan Kolmogorov-Smirnov (K-S) table, dengan menggunakan hasil olahan SPSS kesimpulan dapat ditarik dengan melihat Sig (2-tailed). Jika Sig (2-tailed) > a $(0,05)$ maka dapat disimpulkan bahwa residual yang dianalisis terdistribusi normal (Ghozali, 2016:154).

\section{Uji Multikolinearitas}

Model regresi yang baik seharusnya tidak terjadi korelasi antara variabel bebas. Multikolinearitas dapat dilihat dari nilai tolerance ataupun variance inflation factor (VIF). Kedua ukuran ini menunjukkan setiap variabel independen manakah yang dijelaskan oleh variabel independen lainnya. Jadi nilai tolerance rendah sama dengan nilai VIF tinggi. Nilai cut off yang umum dipakai untuk menunjukkan adanya multikolinearitas adalah nilai tolerance $>0,10$ atau nilai $\mathrm{VIF}<10$.

Uji Heteroskedastisitas

Model regresi yang baik adalah yang bebas dari heteroskedastisitas, yaitu varians dari residual satu pengamatan ke pengamatan lain tetap. Mendeteksi ada atau tidaknya indikasi

heteroskedaktisitas, digunakan metode Glejser yaitu dengan meregresi nilai absolut residual dari model yang diestimasi terhadap variabel independen (Ghozali, 2016:134). Model regresi tidak mengandung heteroskedastisitas apabila probabilitas signifikansinya diatas tingkat kepercayaan 0,05.

Analisis Regresi Linear Berganda

Metode analisis data yang digunakan dalam penelitian ini yaitu analisis regresi linear berganda. Untuk memecahkan permasalahan yang ada, maka dipergunakan alat analisis regresi linier berganda dengan persamaan sebagai berikut: $Y=\beta_{1} X_{1}+\beta_{2} X_{2}+\beta_{3} X_{3}+\beta_{4} X_{4}+\beta_{5} X_{5}+e$ Keterangan: $\mathrm{Y}=$ Gelar Sarjana (S1) $\mathrm{X}_{1} \quad=$ Perilaku Belajar $\mathrm{X}_{2} \quad=$ Motivasi Belajar $\mathrm{X}_{3} \quad=$ Kecerdasan Emosional $\mathrm{X}_{4} \quad=$ Kecerdasan Intelektual $\mathrm{X}_{5} \quad=$ Kecerdasan Spiritual $\beta_{1}-\beta_{5}=$ Koefisien Regresi $\mathrm{e}=$ Standar Error 
HASIL DAN PEMBAHASAN

\section{Hasil Uji Validitas dan Reliabilitas}

Hasil uji validitas indikator pertanyaan tentang variabel didapatkan bahwa semua item pertanyaan valid sehingga bisa digunakan untuk analisis selanjutnya. Kriteria valid ini dilihat dari nilai signifikansi yang kurang dari 0,05. Uji reliabilitas dilakukan untuk mengetahui konsistensi dan akurasi data yang dikumpulkan dari penggunaan instrumen, bila data yang diperoleh kurang valid dan kurang reliabel maka akan menghasilkan kesimpulan yang bias. Hasil reliabilitas data ditunjukkan oleh nilai cronbach alpha dari masingmasing variabel penelitian yang diuji. Hasil uji menunjukkan bahwa nilai cronbach alpha untuk semua variabel adalah lebih dari 0,60 sehingga instrumen penelitian dikatakan reliabel dan dapat digunakan untuk mengukur variabel.

\section{Uji Multikolinieritas}

Untuk mendeteksi apakah pada model regresi ditemukan adanya korelasi antarvariabel bebas dilakukan uji multikolinearitas. Pengaruh dari multikolinearitas hanyalah sulit untuk mendapatkan koefisien dengan standard error yang kecil. Hal ini sering terjadi jika jumlah observasi kecil. Indikasi adanya multikolinearitas dapat ditunjukkan oleh nilai VIF (Variance Inflation Factor), ukuran ini menunjukkan setiap variabel independen manakah yang dijelaskan oleh variabel independen lainnya. Dalam uji ini, setiap variabel independen menjadi variabel dependen dan diregres terhadap variabel independen lainnya. Tolerance mengukur variabilitas variabel independen terpilih yang tidak dijelaskan oleh variabel independen lainnya.

Tabel 4 Hasil Uji Asumsi Multikolinieritas

\begin{tabular}{ccc}
\hline Variabel & Tolerance & VIF \\
\hline X1 & 0,234 & 4,268 \\
X2 & 0,483 & 2,068 \\
X3 & 0,355 & 2,815 \\
X4 & 0,170 & 5,886 \\
X5 & 0,304 & 3,289 \\
\hline
\end{tabular}

Sumber: Data primer diolah (2018) 
Datrini, Saputra, Wistawan - Analisis Pengaruh Faktor-faktor Psikologis ...

Multikolinearitas dapat dilihat dari nilai tolerance $>0,10$ atau nilai VIF $<10$. Dari tabel dapat dilihat bahwa variabel memiliki nilai VIF lebih kecil dari 10 sehingga mengindikasikan tidak terjadi multikolinieritas.

\section{Uji Heterokodetastisitas}

Model regresi yang baik adalah yang homoskedastisitas atau tidak terjadi heterokedastisitas. Dalam penelitian ini, uji asumsi heterokedastisitas menggunakan uji Glejser dengan meregresikan absolute residual dengan variabel bebas. Heterokedastisitas terjadi jika variabel bebas signifikan mempengaruhi absolute residual. Hasil uji heterokedastisitas didapatkan bahwa nilai signifikansi masing-masing hipotesis lebih besar dari 0,05 (Sig.>0,05).

Tabel 5 Hasil Uji Asumsi Heterokedastisitas

\begin{tabular}{cc} 
Variabel & Signifikansi \\
\hline X1 & 0,842 \\
X2 & 0,735 \\
X3 & 0,996 \\
X4 & 0,086 \\
X5 & 0,317
\end{tabular}

Sumber: Data primer diolah (2018)

\section{Uji Normalitas}

Uji asumsi normalitas dilakukan pada residual hasil regresi. Dari hasil uji kolmogorov smirnov terhadap residual hasil regresi tersebut didapatkan bahwa nilai signifikansi lebih dari 0,05 sehingga asumsi kenormalan galat regresi terpenuhi, sehingga dapat dinyatakan bahwa data residual terdistribusi secara normal. Tabel 6 berikut ini menunjukkan hasil uji asumsi normalitas dengan menggunakan statistik uji kolmogorov smirnov.

\section{Hasil Uji Hipotesis}

Terdapat lima hipotesis dalam penelitian ini yaitu yang pertama disebut hipotesis satu yang bertujuan untuk mengetahui apakah perilaku belajar berpengaruh signifikan terhadap keberhasilan mendapat gelar sarjana di bidang akuntansi, hipotesis dua untuk mengetahui apakah motivasi belajar berpengaruh signifikan terhadap keberhasilan 
mendapat gelar sarjana di bidang terhadap keberhasilan mendapat akuntansi, hipotesis tiga untuk gelar sarjana di bidang akuntansi mengetahui kecerdasan emosional dan yang kelima disebut hipotesis berpengaruh signifikan terhadap lima untuk mengetahui apakah keberhasilan mendapat gelar sarjana kecerdasan spiritual berpengaruh di bidang akuntansi, hipotesis empat untuk mengetahui kecerdasan intelektual berpengaruh signifikan signifikan terhadap keberhasilan mendapat gelar sarjana di bidang akuntansi.

Tabel 6 Hasil Uji Asumsi Normalitas

\begin{tabular}{llr}
\hline & & \multicolumn{2}{c}{$\begin{array}{r}\text { Unstandardized } \\
\text { Residual }\end{array}$} \\
\hline $\mathrm{N}$ & Mean & .0000000 \\
Normal & & \\
& Std. Deviation & 1.60566416 \\
Most Extreme & Absolute & .037 \\
Differences & & .037 \\
& Positive & -.037 \\
Kolmogorov- & Negative & .367 \\
Smirnov $Z$ & & .999 \\
Asymp. Sig. (2- & & \\
tailed) & & \\
\hline uber: Data primer diolah (2018) &
\end{tabular}

Dari analisis regresi (Tabel 7) dapat dilihat bahwa variabel yang berpengaruh signifikan terhadap keberhasilan mendapat gelar sarjana di bidang akuntansi adalah variabel perilaku belajar, motivasi belajar, kecerdasan emosional, kecerdasan intelektual dan kecerdasan spiritual atau dengan kata lain bahwa kseluruhan variabel independen berpengaruh terhadap keberhasilan mendapat gelar sarjana di bidang akuntansi. Nilai signifikansi variabel perilaku belajar sebesar 0,004, variabel motivasi belajar sebesar 0,001, nilai signivikansi variabel kecerdasan emosional, kecerdasan intelektual, dan kecerdasan spiritual berturut-turut adalah 0,006, 0,002 dan 0,014 berarti bahwa melalui uji 
regresi berganda variabel perilaku belajar, motivasi belajar, kecerdasan emosional, kecerdasan intelektual dan kecerdasan spiritual terbukti berdampak terhadap keberhasilan mendapat gelar sarjana di bidang akuntansi.

Tabel 7 Hasil Uji Hipotesis

\begin{tabular}{|c|c|c|c|c|c|c|}
\hline & \multirow[b]{2}{*}{ Model } & \multicolumn{2}{|c|}{$\begin{array}{c}\text { Unstandardized } \\
\text { Coefficients }\end{array}$} & \multirow{2}{*}{$\begin{array}{c}\text { Standardized } \\
\text { Coefficients }\end{array}$} & \multirow[b]{2}{*}{ 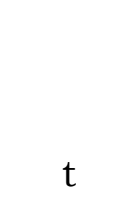 } & \multirow[b]{2}{*}{ Sig. } \\
\hline & & $\mathrm{B}$ & Std. Error & & & \\
\hline \multirow[t]{6}{*}{1} & (Constant) & .351 & 1.077 & & .326 & .745 \\
\hline & $\mathrm{X} 1$ & .126 & .042 & .283 & 2.988 & .004 \\
\hline & $\mathrm{X} 2$ & .126 & .035 & .237 & 3.603 & .001 \\
\hline & X3 & .112 & .040 & .216 & 2.811 & .006 \\
\hline & $\mathrm{X} 4$ & .319 & .099 & .359 & 3.228 & .002 \\
\hline & $\mathrm{X} 5$ & .201 & .081 & .208 & 2.497 & .014 \\
\hline
\end{tabular}

Sumber: Data diolah (2018)

\section{Pembahasan}

Perilaku belajar secara psikologis sangat berhubungan dengan seberapa jauh pengetahuan yang didapat oleh seseorang. Dalam penelitian ini, menyatakan bahwa perilaku belajar berpengaruh signifikan terhadap keberhasilan mahasiswa meraih gelar sarjana di bidang akuntansi, hal ini sekaligus menyatakan bahwa hipotesis satu diterima. Perilaku seseorang dalam menggali informasi yang dalam dan meningkatkan pengetahuan sangatlah berbeda-beda sehingga membutuhkan pendekatan yang berbeda pula untuk sampai pada sebuah keberhasilan. Hasil penelitian ini sejalan dengan Rokhana (2016) dan Trisnawati, dkk (2017).

Hipotesis kedua yaitu menyatakan motivasi belajar berpengaruh signifikan terhadap keberhasilan mahasiswa meraih gelar sarjana di bidang akuntansi dapat dinyatakan diterima. Artinya bahwa motivasi diri secara psikologis memiliki kemampuan yang luar biasa untuk mengembalikan gairah seseorang terhadap apa yang menjadi tujuan dan cita-cita nya. Berbagai motivasi yang dapat membangkitkan semangat diantaranya adalah semangat untuk kuliah, mengikuti pelajaran serta mengerjakan tugas kuliah adalah bagian kecil dari peran 
motivasi

dalam

mencapai

kessuksesan. Peran yang lebih besar lagi dari suatu motivasi belajar terhadap kesuksesan adalah menjadikan seseorang memiliki pandangan hidup kedepan dan berorientasi masa depan. Hasil penelitian ini sejalan dengan penelitian sebelumnya yang dilakukan oleh Syamsuddin (2014) yang menyimpulkan bahwa motivasi belajar berpengaruh positif terhadap prestasi belajar mahasiswa akuntansi.

Hipotesis ketiga dinyatakan diterima yang menyatakan bahwa kecerdasan emosional memiliki pengaruh yang signifikan terhadap keberhasilan mahasiswa akuntansi meraih gelar sarjana. Hal ini dapat secara luas berdampak bahwa sebenarnya tingkat pengendalian emosional atau sering disebut tingkat kedewasaan berpikir seseorang mampu meningkatkan daya penerimaan seseorang tersebut menjadi lebih baik dan seimbang. Hasil penelitian ini menyatakan bahwa seseorang dapat menempatkan emosinya pada porsi yang tepat, memilih kepuasan, dan mengatur suasana hati. Penelitian ini sejalan dengan hasil penelitian dari Atmadja dan Saputra (2015), Rokhana (2016) dan Hatima, dkk (2017) yang menyatakan bahwa kecerdasan emosional berpengaruh terhadap prestasi mahasiswa.

Hipotesis keempat dinyatakan diterima yaitu menyebutkan bahwa kecerdasan intelektual seseorang berpengaruh signifikan terhadap keberhasilan mahasiswa akuntansi meraih gelar sarjana. Kecerdasan intelektual yang dimaksud dalam hal ini adalah kemampuan seseorang secara intelektual. Kecerdasan intelektual sering juga disebut inteligensi, yang berarti kemampuan kognitif yang dimiliki suatu organisme untuk menyesuaikan diri secara efektif pada lingkungan yang komplek dan selalu berubah serta dipengaruhi oleh faktor genenti. Kemampuan intelektual seseorang memiliki pengaruh yang positif terhadap kesuksesan atau keberhasilan seseorang dalam meraih sesuatu. Intelektual juga dapat diasumsikan sebagai suatu kreatifitas sehingga seseorang ketika memiliki kreatifitas tinggi maka akan memiliki tingkat kepuasan yang tinggi pula yang berdampak pada keberhasilan kinerjanya (Atmadja dan Saputra, 2018). Secara keseluruhan manusia telah memiliki kecerdasan intelektual pada masing-masing keilmuan, sehingga dapat disimpulkan bahwa mahasiswa akuntansi wajib memiliki pengetahuan yang luas tentang akuntansi namun tidak sebatas pada 
ilmu akuntansi dalam angka-angka saja, namun melainkan secara kompleks, karena ilmu akuntansi adalah ilmu yang sangat luas dan kompleks baik secara teori maupun praktis. Hasil penelitian ini sejalan dengan penelitian sebelumnya yang dilakukan oleh Onah (2015) dan Hatima, dkk., (2017).

Hipotesis terakhir yaitu hipotesis kelima dinyatakan diterima yaitu bahwa kecerdasan spiritual berpengaruh signifikan terhadap keberhasilan mahasiswa akuntansi meraih gelar sarjana. Kecerdasan Spriritual adalah kecerdasan jiwa, keceerdasan yang berada didalam di diri yang dalam, diluar ego atau pikiran sadar. Kita dapat menggunakan kecerdasan spiritual untuk menjadi lebih cerdas secara spiritual dan beragama. Spiritualis mahasiswa yang cerdas akan mampu membantu dalam memecahkan permasalahan sehingga mahasiswa dapat bersikap tenang dalam menghadapi masalah-masalah kendala- kendala dalam proses mendapatkan gelar sarjana (S1). Hasil penelitian ini sejalan dengan penelitian sebelumnya yaitu dari Atmadja dan Saputra (2014).

\section{KESIMPULAN, IMPLIKASI DAN KETERBATASAN PENELITIAN}

Variabel yang berpengaruh signifikan terhadap keberhasilan mendapat gelar sarjana di bidang akuntansi adalah variabel perilaku belajar, motivasi belajar, kecerdasan emosional, kecerdasan intelektual dan kecerdasan spiritual atau dengan kata lain bahwa kseluruhan variabel independen berpengaruh terhadap keberhasilan mendapat gelar sarjana di bidang akuntansi. Nilai signifikansi variabel perilaku belajar sebesar 0,004, variabel motivasi belajar sebesar 0,001, nilai signifikansi variabel kecerdasan emosional, kecerdasan intelektual, dan kecerdasan spiritual berturut-turut adalah 0,006, 0,002 dan 0,014 berarti bahwa melalui uji regresi berganda variabel perilaku belajar, motivasi belajar, kecerdasan emosional, kecerdasan intelektual dan kecerdasan spiritual terbukti berdampak terhadap keberhasilan mendapat gelar sarjana di bidang akuntansi.

Penelitian ini menitik fokuskan pada mahasiswa akuntansi di Universitas negeri dan swasta di provinsi Bali sehingga perlu diperluas pada obyek penelitiannya. Selanjutnya, faktor psikologis masih dapat dikembangkan seperti misalnya locus of control, budaya organisasi, 
kemampuan komunikasi ataupun yang lainnya. Penggunaan kuesioner menyebabkan hasil penelitian tidak dapat dikonfirmasi sehingga perlu dikolaborasikan dengan metode penelitian secara kualitatif, dan menggunakan mix method.

\section{REFERENSI}

Atmadja, A.T. dan K.A.K. Saputra. (2014). The Effect Of Emotional Spiritual Quotient (ESQ) To Ethical Behavior In Accounting Profession With Tri Hita Karana Culture's As A Moderating Variable. Research Journal of Finance and Accounting, Vol.5, No.7, Page.187-196.

Atmadja, A.T dan K.A.K. Saputra. (2015). The Effect of Total Quality Management, Emotional Intelligence, Critical Sociology, Creativity and Mentality of Education Accounting. International Research Journal of Finance and Economics, Issue 139, Page. 47-61,

Atmadja, A.T dan K.A.K. Saputra. (2018). Pengaruh Budaya Universitas Terhadap Kinerja Mahasiswa Akuntansi Dengan Kreativitas Sebagai Variabel Moderasi (Studi Pada Mahasiswa Akuntansi Di Perguruan Tinggi SeKabupaten Buleleng). Jurnal Akuntansi Aktual, Vol. 5, No. 1, hlm. 22-30.

Ghozali, Imam. (2016). Aplikasi Analisis Multivariate Dengan Program IBM SPSS 23. Edisi Kedelapan, Penerbit Universitas Diponegoro.
Hardiansyah. (2014). Pengaruh Gaya Belajar Terhadap Prestasi Akademik Mahasiswa Fakultas Kedokteran. Jurnal Media Medika Muda

Husein, Umar. 2008. Metode Penelitian Untuk Skripsi dan Tesis Bisnis. Jakarta. PT Rajagrafindo Persada

Indriaty, Novica. (2013). Pengaruh Persepsi Mahasiswa tentang Metode Mengajar, Kemandirian dan Lingkungan Belajar terhadap Prestasi Mahasiswa Jurusan Akuntansi Angkatan 2010 Universitas Maritim Raja Ali Haji. Jurnal Akuntansi. Tanjungpinang

Hatima, dkk (2017). Pengaruh Kecerdasan Intelektual Dan Kecerdasan Emosional Terhadap Prestasi Akademik Mahasiswa Manajemen Fakultas Ekonomi Universitas Tadulako. Jurusan Manajemen, Fakultas Ekonomi, Universitas Tadulako

Rokhana, L.A. (2016). Pengaruh Kecerdasan Emosional, Perilaku Belajar Dan Minat Belajar Terhadap Tingkat Pemahaman Akuntansi. Jurnal Fakultas Ekonomika dan Bisnis UNTAG Semarang.

Marita, Sri Suryaningsum, dan Hening Naafi Shaalih. (2008). Kajian Empiris atas Perilaku Belajar dan Kecerdasan Emosional dalam Mempengaruhi Stres Kuliah Mahasiswa Akuntansi. Simposium Nasional Akuntansi XI Pontianak.

Melandy, Rissyo dan Nurna Aziza. (2006). Pengaruh Kecerdasan Emosional Terhadap Tingkat Pemahaman Akuntansi, Kepercayaan Diri Sebagai 
Variabel Pemoderasi.

Simposium Nasional Akuntansi IX Padang.

Mulawarman, Aji Dedi. (2007). Pensucian Pendidikan Akuntansi Episode Dua: Hiper View of Learning dan Implementasinya. The First Accounting Season: Revolution of Accounting Education. Bandung.

Sugiyono. (2017). Metode Penelitian Kuantitatif Kualitatif dan $R \& D$. Badung: Alfabeta.

Suryaningrum, Sri, Sucahyo Heriningsih, Afifah Afuwah. (2004). Pengaruh Pendidikan Tinggi Akuntansi Terhadap Kecerdasan Emosional.

Denpasar. Simposium Nasional akuntansi VII

Trisnawati, Eka Indah dan Sri Suryaningrum. (2003). Pengaruh Kecerdasan Emosional Terhadap Tingkat Pemahaman Akuntansi, Simposium Nasional Akuntansi VI, Surabaya.

Trisnawati, dkk (2017). Pengaruh Kepercayaan Diri, Perilaku Belajar Dan Kecerdasan Emosional Terhadap Prestasi Belajar Mahasiswa Prodi Akuntansi Umrah. Jurnal Universitas Maritim Raja Ali Haji. 